\title{
Prison Service and cooperation in system of safety
}

\section{Służba Więzienna a współdziałanie w systemie bezpieczeństwa}

\author{
Andrzej Borowski \\ Department of Sociology and Social Works, Faculty of Education and Philosophy, \\ Pomeranian University in Słupsk, 64 Westerplatte St., 76-200 Słupsk, Poland \\ E-mail address: aubor@poczta.onet.pl
}

\begin{abstract}
Prison service in view of total character and place of executable task is enforced affirmation of safety on purpose for with other discretional groups for optimization of operation society having cooperation. Operations related with assuring safety and there must be fitted cooperation affect for potential sources of threats new threats systematically appearing forcefully.
\end{abstract}

Keywords: safety; penitentiary; total institution; cooperation; groups of discretional

\section{STRESZCZENIE}

Służba Więzienna z uwagi na totalny charakter i miejsce wykonywanych zadań mających na celu zapewnienie bezpieczeństwa społeczeństwu zmuszona jest do współdziałania $\mathrm{z}$ innymi grupami dyspozycyjnymi $\mathrm{w}$ celu optymalizacji swoich działań. Działania związane $\mathrm{z}$ zapewnianiem bezpieczeństwa i współdziałaniem muszą być systematycznie dostosowywane do pojawiających się nowych zagrożeń by skutecznie oddziaływać na potencjalne źródła zagrożeń.

Slowa kluczowe: bezpieczeństwo; jednostka penitencjarna; instytucja totalna; współdziałania; grupy dyspozycyjne

\section{WPROWADZENIE}

Służba Więzienna będąc jedną z państwowych służb dyspozycyjnych wypełnia szereg zadań w systemie bezpieczeństwa państwa. Zadania te wiązą się z utrzymywaniem porządku i bezpieczeństwa na terenie jednostek penitencjarnych oraz współdziałaniu z innymi służbami dyspozycyjnymi w realizacji ich zadań.Aby właściwie przygotować się do wykonywanych zadań funkcjonariusze Służby Więziennej poddawani są szkoleniom wstępnym, zasadnicznym i specjalistycznym. Zadania przed jakimi stoi Służba Więzienna można scharakteryzować bazując na jednej z wielu istniejących typologii [1-9]. 


\section{TYPOLOGIE ZADAŃ Z ZAKRESU BEZPIECZEŃSTWA JEDNOSTEK PENITENCJARNYCH}

a) Kryterium podmiotowo-funkcjonalne

- podmioty kierownicze (decyzje, koordynacja, opiniowanie, działania sztabowe) CZSW, OISW

- podmioty wykonawcze (realizujące zadania, planistyczne, edukacyjne, szkoleniowe, naukowo-badawcze, operacyjne) COSSW, ODK SW,

b) Kryterium warunków funkcjonowania jednostek penitencjarnych

- stan czuwania i doraźnego reagowania /szkolenia i bieżąca realizacja zadań z zakresu bezpieczeństwa/

- sytuacja kryzysowa /powiadamianie współdziałających służby dyspozycyjnych/

c) Kryterium etapu realizacji

- zadania przygotowawcze /szkolenie podstawowe, specjalistyczne i permanentne/

- zadania zapobiegawcze /działania profilaktyczne /

- zadania interwencyjne /użycie sił własnych SW i instytucji współpracujących/

- zadania odtwarzające /rekonstrukcyjne/

d) Kryterium zasięgu przestrzennego

- zasięg lokalny /jednostka penitencjarna i jej bezpośrednie otoczenie/

- zasięg regionalny /Okręgowy Inspektorat SW/

- zasięg krajowy/Centralny Zarząd SW/

- zasięg międzynarodowy /porozumienia o współpracy między SW a służbami w innych państwach/

Mimo iż odpowiedzialność za bezpieczeństwo publiczne państwa spoczywa w Polsce na wielu podmiotach określanych jako grupy dyspozycyjne, to taki stan rzeczy wskazuje na potrzebę koordynacji i współdziałania a troska o bezpieczeństwo również poszukiwania racjonalnych systemów jakości realizowanych zadań. Wzrastające poczucie zagrożenia spowodowane wzrostem przestępczości, funkcjonującymi dynamicznie organizacjami mafijnymi i terrorystycznymi, prezentowaniem w mediach scen przemocy oraz nasilającymi się zjawiskami agresji w zachowaniach ludzi, katastrof i awarii technicznych wymusza poszukiwanie metod gwarantujących likwidację lub chociażby ograniczenie ich negatywnych zjawisk. Mimo szerokiego zainteresowania problemami bezpieczeństwa na dzień dzisiejszy nie wypracowano w szerszej skali jednolitego, uporządkowanego systemu pojęciowego, który obecnie w zależności od intencji autorów przekazu, prezentuje szerokie lub wąskie pojmowanie tego zagadnienia.

\section{PODLEGLOŚĆ GRUP DYSPOZYCYJNYCH}

a) Prezes Rady Ministrów:

- Agencja Bezpieczeństwa Wewnętrznego

- Agencja Wywiadu

- Centralne Biuro Antykorupcyjne

b) Ministerstwo Obrony Narodowej

- Wojsko Polskie

- Służba Kontrwywiadu Wojskowego 
- Służba Wywiadu Wojskowego

- Żandarmeria Wojskowa

c) Ministerstwo Spraw Wewnętrznych

- Policja

- Straż Pożarna

- Straż Graniczna

- Biuro Ochrony Rządu

d) Ministerstwo Finansów

- Służba Celna

e) Ministerstwo Sprawiedliwości

- Służba Więzienna

\section{WSPÓŁUDZIAŁ GRUP DYSPOZYCYJNYCH W WYKONANIU KARY POZBAWIENIA WOLNOŚCI}

Artykuł 38. Kodeksu karnego wykonawczego stanowi, iż w wykonywaniu kar, środków karnych, zabezpieczających i zapobiegawczych w szczególności związanych z pozbawieniem wolności, mogą współdziałać m.in. instytucje publiczne. Na podstawie tego zapisu Służba Więzienna realizuje następujące porozumienia i umowy o współpracy:

A) Porozumienie o współpracy zawarte w Warszawie w dniu 6.01.2009 r. pomiędzy Dyrektorem Generalnym Służby Więziennej a Komendantem Głównym Państwowej Straży Pożarnej;

B) Porozumienie zawarte w Warszawie w dniu 19.06.2009 r. pomiędzy Dyrektorem Generalnym Służby Więziennej a Komendantem Głównym Policji;

\section{WSPÓLPRACA MIĘDZYNARODOWA SW W ZAKRESIE BEZPIECZEŃSTWA}

W zakresie współpracy międzynarodowej SW nawiązuje partnerskice stosunki z przedstawicielami innych systemów penitencjarnych, polegające na wymianie doświadczeń w zakresie wykonywania kary pozbawienia wolności i tymczasowego aresztowania, prezentowanie polskich rozwiązań stosowanych w pracy penitencjarnej, działania pomocowe na rzecz rozwijających się systemów penitencjarnych, promowanie polskiej myśli technicznej oraz intelektualnej, zbieranie informacji, które mogą być wykorzystane dla wprowadzania nowych rozwiązań systemowych lub technicznych poprawiających bezpieczeństwo i skuteczność w realizacji zadań, do jakich jest powołana Służba Więzienna.

Działalność międzynarodowa oparta jest o ustalenia zawarte $w$ podpisanych porozumieniach o współpracy pomiędzy jednostkami organizacyjnymi służb na szczeblach: centralnym, okręgowym oraz podstawowym. W chwili obecnej polska Służba Więzienna realizuje porozumienia o współpracy międzynarodowej z:

A) Departamentem Służby Więziennej Republiki Litewskiej przy Ministerstwie Sprawiedliwości (podpisano 19 września 2007 r. w Wilnie na lata 2007-2010, z możliwością przedłużenia o kolejne 3 lata). 
B) Departamentem Więziennictwa Ministerstwa Sprawiedliwości Gruzji (podpisano w marcu 2008 r. w Warszawie i Tbilisi na lata 2008 - 2010, z możliwością przedłużenia o kolejne 3 lata).

C) Wydziałem Instytucji Penitencjarnych Teksańskiego Departamentu Prawa Kryminalnego Stanów Zjednoczonych Ameryki Północnej oraz Centrum Prawa Kryminalnego Uniwersytetu Stanowego Sama Houstona w Huntsville w Teksasie, w Stanach Zjednoczonych Ameryki Północnej (podpisano 28 maja 2008 r. w Warszawie).

D) Komitetem ds. Systemu Karno-Wykonawczego Ministerstwa Sprawiedliwości Republiki Kazachstanu (podpisano w Warszawie 2 kwietnia 2009 r. na czas nieokreślony, z możliwością odstąpienia przez każdą ze stron porozumienia w dowolnym czasie).

E) Głównym Zarządem Karno-Wykonawczym Ministerstwa Sprawiedliwości Republiki Kirgistanu (podpisano w Warszawie 18 maja 2009 r. na czas nieokreślony, z możliwością odstąpienia przez każdą ze stron porozumienia w dowolnym czasie).

F) Federalną Służbą Wykonania Kar Federacji Rosyjskiej (podpisano 10 sierpnia 2010 r. w Warszawie na czas nieokreślony, z możliwością odstąpienia przez każdą ze stron w dowolnym czasie).

G) Generalnym Departamentem Wykonywania Wyroków Sądowych Mongolii (podpisano 29 sierpnia 2010 r. w Ułan Bator na 3 lata /2010 - 2013/ z możliwością przedłużenia na następne 3 lata, jeżeli żadna ze stron nie wymówi porozumienia w okresie 6 miesięcy przed terminem jego obowiązywania).

H) Państwową Służbą Penitencjarną Ukrainy (podpisano 12 maja 2011 r. w Kijowie na czas nieokreślony z możliwością rozwiązania po 6 miesiącach od czasu poinformowania Strony o woli rozwiązania porozumienia przez drugą Stronę).

I) Krajową Szkołą Administracji Penitencjarnej (ENAP) w Agen we Francji (podpisano 8 września 2011 r. w Agen/Francja/ na 3 lata z możliwością przedłużenia odpowiednim aneksem, po wyrażeniu uprzedniej zgody przez Strony porozumienia).

J) Służbą Więzienną Republiki Czeskiej (podpisano w czerwcu 2012 r. w Warszawie i w Pradze, bezterminowo, z możliwością wypowiedzenia przez każdą ze stron z trzymiesięcznym wyprzedzeniem).

Oprócz porozumień zawartych przez dyrektora generalnego Służby Więziennej funkcjonuje 39 podpisanych porozumień, z czego 6 zawartych jest na szczeblu okręgowym (Okręgowe Inspektoraty Służby Więziennej w Białymstoku, Łodzi, Poznaniu, Rzeszowie, Warszawie i Wrocławiu), 30 na szczeblu podstawowym (areszty śledcze, zakłady karne) oraz 2 zawarte przez Centralny Ośrodek Szkolenia Służby Więziennej w Kaliszu i 1 przez Ośrodek Szkolenia Służby Więziennej w Kulach.

Największą ilość porozumień o współpracy międzynarodowej jednostki organizacyjne więziennictwa realizowały w 2012 r. z partnerami z Czech (20 porozumień partnerskich), Niemiec (8) i Słowacji (6). W roku 2012 polskie więziennictwo prowadziło współpracę z systemami więziennymi lub partnerami działającymi na rzecz więziennictwa z: Austrii, Belgii, Białorusi, Czech, Danii, Estonii, Francji, Finlandii, Gruzji, Holandii, Izraela, Kirgistanu, Litwy, Łotwy, Mołdawii, Niemiec, Norwegii, Federacji Rosyjskiej, Francji, Portugalii, Rumunii, Słowacji, Tadżykistanu, Turcji, Ukrainy, USA, Węgier, Wielkiej Brytanii i Włoch. 


\section{ZARZĄDZANIE KRYZYSOWE W SW}

Sprawy zarządzania kryzysowego reguluje Ustawa $z$ dnia 26 kwietnia 2007 r. o zarządzaniu kryzysowym (Dz. U. z 2007 r. Nr 89, poz. 590 z późn zm.) Zarządzanie kryzysowe obejmuje cztery fazy: zapobieganie, przygotowanie, reagowanie i odbudowa. Główne dokumenty planistyczne to: Raport o zagrożeniach bezpieczeństwa narodowego, Krajowy Plan Zarządzania Kryzysowego, Narodowy Program Ochrony Infrastruktury Krytycznej. Ochrona infrastruktury oznacza wszelkie działania i współdziałania zmierzające do zapewnienia funkcjonalności, ciągłości działań i integralności IK. Celem tych działań jest zapobieganie zagrożeniom, ryzyku lub eliminacja słabych punktów oraz ograniczenia i neutralizacji ich skutków przez szybkie odtworzenie tej infrastruktury na wypadek awarii, ataków i innych zdarzeń zakłócających jej prawidłowe funkcjonowanie.

Współudział w usuwaniu skutków zakłóceń nie zwalnia właścicieli infrastruktury od odpowiedzialności za jej ochronę i dalsze działania powstrzymujące rozprzestrzenianie się zagrożenia. Ochrona infrastruktury jest obowiązkiem właściciela.

\section{ZARZĄDZANIE SYTUACJAMI NADZWYCZAJNYMI W SW}

\section{Wykaz zdarzeń nadzwyczajnych:}

\section{Część I, Kategoria A}

1. Groźne zakłócenie bezpieczeństwa - zdarzenie zakłócające funkcjonowanie jednostki organizacyjnej, w trakcie którego doszło do śmierci, naruszenia nietykalności osób, zniszczenia mienia lub strat znacznej wartości, tj. przekraczającej wysokość 50-krotnego przeciętnego miesięcznego wynagrodzenia obliczonego na podstawie danych ogłaszanych przez Prezesa Głównego Urzędu Statystycznego./ współdziałanie z policją, strażą pożarną, pogotowiem ratunkowym/

2. Bunt - zdarzenie naruszające bezpieczeństwo jednostki organizacyjnej, polegające na zbiorowym wystąpieniu osadzonych poprzez samowolne opuszczenie wyznaczonych miejsc pobytu lub pracy albo ich opanowanie i niepodporządkowanie się wydawanym poleceniom /współdziałanie z policją, strażą pożarną, pogotowiem ratunkowym/

3. Groźne zakłócenie porządku - zdarzenie w poważnym stopniu zakłócające funkcjonowanie jednostki organizacyjnej, w trakcie którego nie doszło do naruszenia nietykalności osób lub zniszczenia mienia.

4. Ucieczka osoby pozbawionej wolności z terenu zakładu karnego typu zamkniętego lub aresztu śledczego /współdziałanie z policją/.

5. Nieuprawnione ujawnienie informacji niejawnych albo utracenie dokumentu zawierającego takie informacje./ABW, policja/

6. Samobójstwo osadzonego /prokuratura/

7. Śmierć osadzonego lub innej osoby przebywającej na terenie jednostki organizacyjnej albo ciężkie uszkodzenie ciała na skutek działania funkcjonariusza, pracownika lub innej osoby albo psa służbowego /policja/

8. Utrata broni palnej lub amunicji przez funkcjonariusza albo inną osobę przebywającą na terenie jednostki organizacyjnej /policja/

9. Napaść na jednostkę organizacyjną lub na konwój /policja/ 
10. Utracenie dokumentu lub nośnika informacji albo nieuprawnione ujawnienie treści dokumentu albo nośnika informacji zawierającego zbiorcze dane osobowe funkcjonariuszy, pracowników lub osadzonych /policja, ABW/

11. Napaść na funkcjonariusza lub pracownika w trakcie wykonywania czynności służbowych /policja/

12. Prowadzenie na terenie jednostki organizacyjnej czynności w zakresie przeszukania funkcjonariusza lub pracownika przez organy policji, ABW, SG, CBA lub innego uprawnionego organu albo jego zatrzymanie przez te organy.

13. Samobójstwo funkcjonariusza albo pracownika /policja, pogotowie ratunkowe/

14. Znalezienie na terenie jednostki organizacyjnej broni palnej, amunicji, materiałów wybuchowych albo innych przedmiotów zawierających substancje mogące zagrażać życiu lub zdrowiu./policja, wojsko-saperzy/

15. Ucieczka osoby pozbawionej wolności w trakcie konwojowania realizowanego przez funkcjonariuszy Służby Więziennej /policja/

16. Wzięcie zakładnika/policja/.

\section{Część II Kategoria B}

1. Ucieczka osoby pobawionej wolności z terenu zakładu karnego typu półotwartego lub otwartego /policja/

2. Zgwałcenie osadzonego.

3. Znęcanie się nad osadzonym.

4. Bójka lub pobicie.

5. Choroba funkcjonariuszy, pracowników lub osadzonych na jednakową jednostkę chorobową, powodująca poważne zakłócenie funkcjonowania jednostki /pogotowie ratunkowe, Sanepid/

6. Zagrożenie zewnętrzne - zdarzenie wywołane czynnikami zewnętrznymi, nie powodujące skutków, o których mowa w części I pkt 1, w szczególności: katastrofa, klęska żywiołowa, pożar /straż pożarna, obrona cywilna/

7. Ujawnienie na terenie jednostki organizacyjnej przedmiotu niebezpiecznego lub niedozwolonego, niewymienionego w części I pkt 14 / policja, wojsko/

8. Popełnienie przez funkcjonariusza albo pracownika czynu noszącego znamiona przestępstwa ściganego z urzędu /policja/

9. Napaść na funkcjonariusza lub pracownika poza służbą /policja

10. Usiłowanie dokonania ucieczki w trakcie konwojowania realizowanego przez funkcjonariuszy Służby Więziennej /policja/

11. Przygotowanie do ucieczki przez osobę pozbawioną wolności lub usiłowanie jej dokonania $\mathrm{z}$ terenu jednostki organizacyjnej /policja/

12. Ucieczka osoby pozbawionej wolności lub usiłowanie dokonania takiej ucieczki w trakcie konwojowania realizowanego przez inne organy uprawnione do konwojowania /policja/ 
13. Samowolne oddalenie się osoby pozbawionej wolności w trakcie pobytu poza terenem jednostki organizacyjnej w systemie bez konwojenta /policja/

14. Usiłowanie dokonania samobójstwa przez funkcjonariusza lub pracownika/policja/

15. Usiłowanie dokonania samobójstwa przez osadzonego.

16. Zgon osadzonego inny niż samobójstwo /policja/

17. Zgon osadzonego w czasie korzystania z zezwolenia na opuszczenie jednostki organizacyjnej /policja/

18. Inne zdarzenie uznane przez dyrektora za zdarzenie nadzwyczajne.

19. Aktualizacja meldunku o zdarzeniu nadzwyczajnym.

Na podstawie: Załacznik do zarządzenia Nr 94/2010 Dyrektora Generalnego Stużby Więziennej $z$ dnia 31 grudnia 2010 r. Załacznik $n r 1$

\section{WSPÓŁPRACA W ZAKRESIE OCHRONY I OBRONY JEDNOSTEK PENITENCJARNYCH}

Kwestie związane ze współpracą służb w zakresie ochrony i obrony jednostek penitencjarnych regulują następujące akty prawne: Rozporządzenie Rady Ministrów z dnia 24.06.2003r. W sprawie obiektów szczególnie ważnych dla bezpieczeństwa i obronności państwa oraz ich szczególnej ochrony

\& 2 pkt. 14 obiekty znajdujące się we właściwości Ministra Sprawiedliwości, Stużby Więziennej oraz jednostek organizacyjnych podlegtych lub nadzorowanych przez Ministra Sprawiedliwości obiekty penitencjarne należa do tzw II kategorii szczególnie chronionych obiektów \& 7 ust. 1 pkt 7 zaktada,że instytucje zarządzajace takimi obiektami organizuja współdziałanie $w$ zakresie dotyczacym szczególnej ochrony tych obiektów

Rozporządzenie Ministra Sprawiedliwości z dnia 31.10.2003r. w sprawie obrony jednostek organizacyjnych Służby Więziennej przewiduje stworzenie w każdej z jednostek penitencjarnych planu obrony zawierającego instrukcje dotyczące postępowania w sytuacjach klęsk żywiołowych, stanów nadzwyczajnych i zabezpieczenia potrzeb obronnych jednostki, współdziałanie odbywa się na bazie porozumień o współpracy z lokalnymi jednostkami Policji, Straży Pożarnej, Straży Granicznej lub Obrony Cywilnej. Rozporządzenie Ministra Sprawiedliwości z dnia 31.10.2003r. w sprawie sposobów ochrony jednostek organizacyjnych Służby Więziennej zakłada, że:

System ochrony może mieć charakter petny/ AŚ i ZK typu zamkniętego/,ograniczony/ZK typu półotwartego/ lub uproszczony/ ZK typu otwartego/. System ochrony jest ustalany w ramach tzw planu ochrony jednostki penitencjarnej. Jednym z załaczników do takiego planu jest zawsze porozumienie w sprawie ustalenia trybu współdziałania jednostki SW z Policja w przypadkach zagrożenia lub naruszenia bezpieczeństwa jednostki penitencjarnej. 


\section{PRZYKŁADY WSPÓŁDZIALANIA SW Z INNYMI INSTYTUCJAMI}

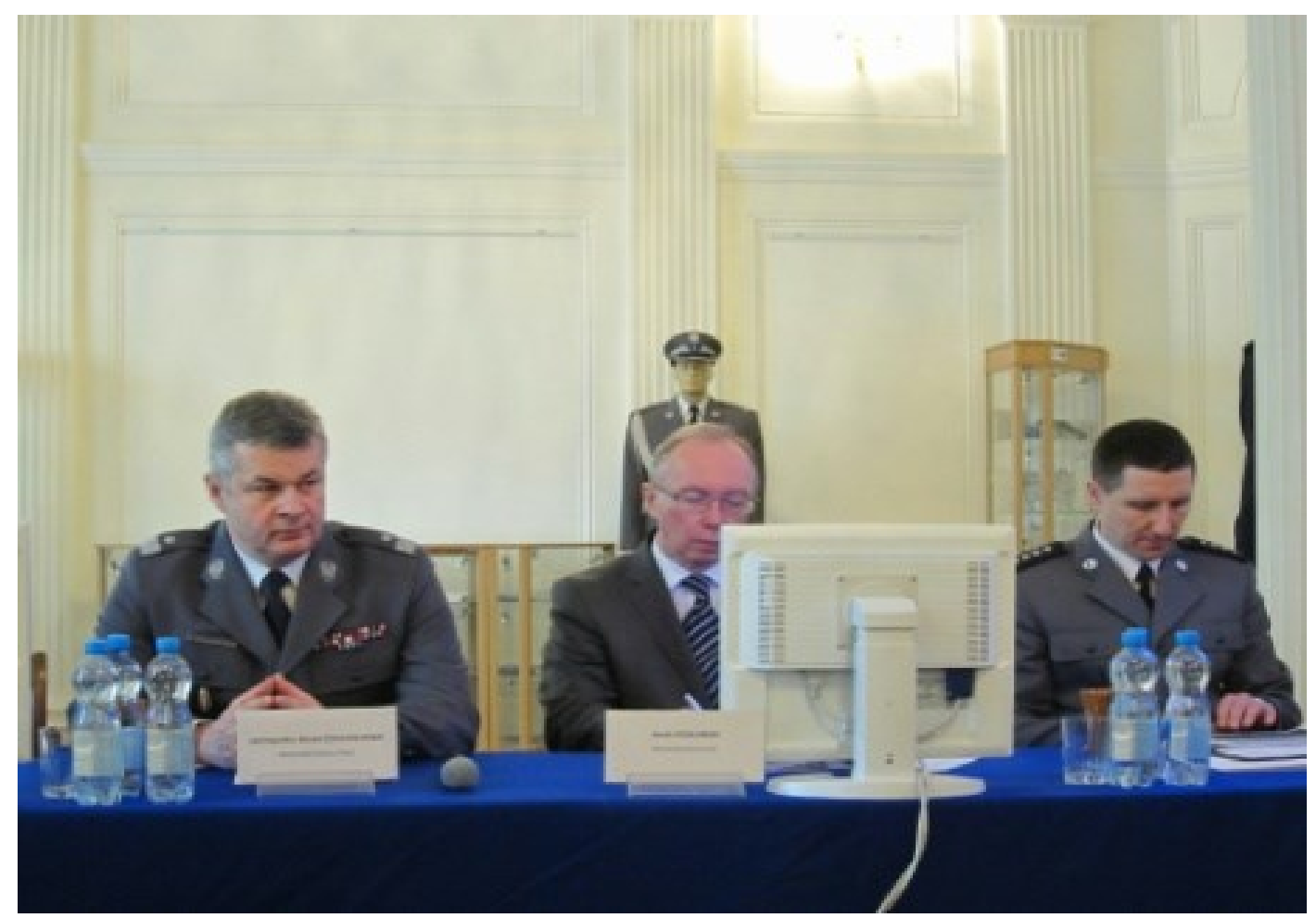

Foto. 1. Udział w rocznych odprawach służb współpracujących z udziałem przedstawicieli SW Policji, Straży Miejskiej, Straży Granicznej, Straży pożarnej, Warszawa /15.01.2013/ oraz /19.02.2013/.

- Zimowa akademia bezpieczeństwa/ pokazy i szkolenia w zakresie samoobrony i udzielania pierwszej pomocy, z udziałem przedstawicieli SW oraz dzieci i młodzieży, Kalisz /styczeń 2013/

- Pomorskie Seminarium Formacji Mundurowych z Systemów Walk Wręcz/Gdańsk/ z udziałem przedstawicieli Straży Granicznej, Policji, Straży Miejskiej, Służby Celnej oraz Marynarki Wojennej, lotnictwa i Żandarmerii Wojskowej

- Warsztaty profilaktyczne dla młodzieży szkół średnich z udziałem przedstawicieli SW i Policji, Lubliniec /8.02.2013/

- Porozumienie o współpracy ze Strażą Graniczną, Łódź, /7.02.2013/

- Organizacja systemu bezpieczeństwa podczas międzynarodowych spotkań i konferencji, z udziałem SW, Policji, ABW ,Straży Granicznej, Warszawa /19.02.2013/

- Szkolenie z zakresu samoobrony dla kobiet, Rawicz /9.03.2013/

- Lider bezpieczeństwa -współpraca z jednostkami samorządu terytorialnymi w zakresie bezpieczeństwa, Olsztyn /12.03.2013/

- Projekt edukacyjno-profilaktyczny „Więzienie - stracony czas” we współpracy SW i Policji, będącego jednąc z części realizacji rządowego programu ograniczania przestępczości i aspołecznych zachowań „Razem bezpieczniej” Warszawa /15.03.2013/ 
- Konferencja dotycząca współdziałania SW ,Policji, i Straży Granicznej z prokuraturą i sądami w realizacji zadań ustawowych, Popowo /25-26.03.2013/

- współpraca ośrodków edukacyjnych służb mundurowych, z udziałem przedstawicieli SW, Policji, MON, Straż Pożarna, Straż Graniczna, Kalisz /27.03.2013/

- Program profilaktyczno-edukacyjny „Na zakręcie”, we współpracy SWi Policji, Sosnowiec /29.03.2013/

- porozumienie o współdziałaniu między SW, a Żandarmerią Wojskową, Lublin /9.04.2013/

- propagowanie idei dozoru elektronicznego we współpracy SW z Policją, Prokuraturą i Sądami, Lublin /15.04.2013/

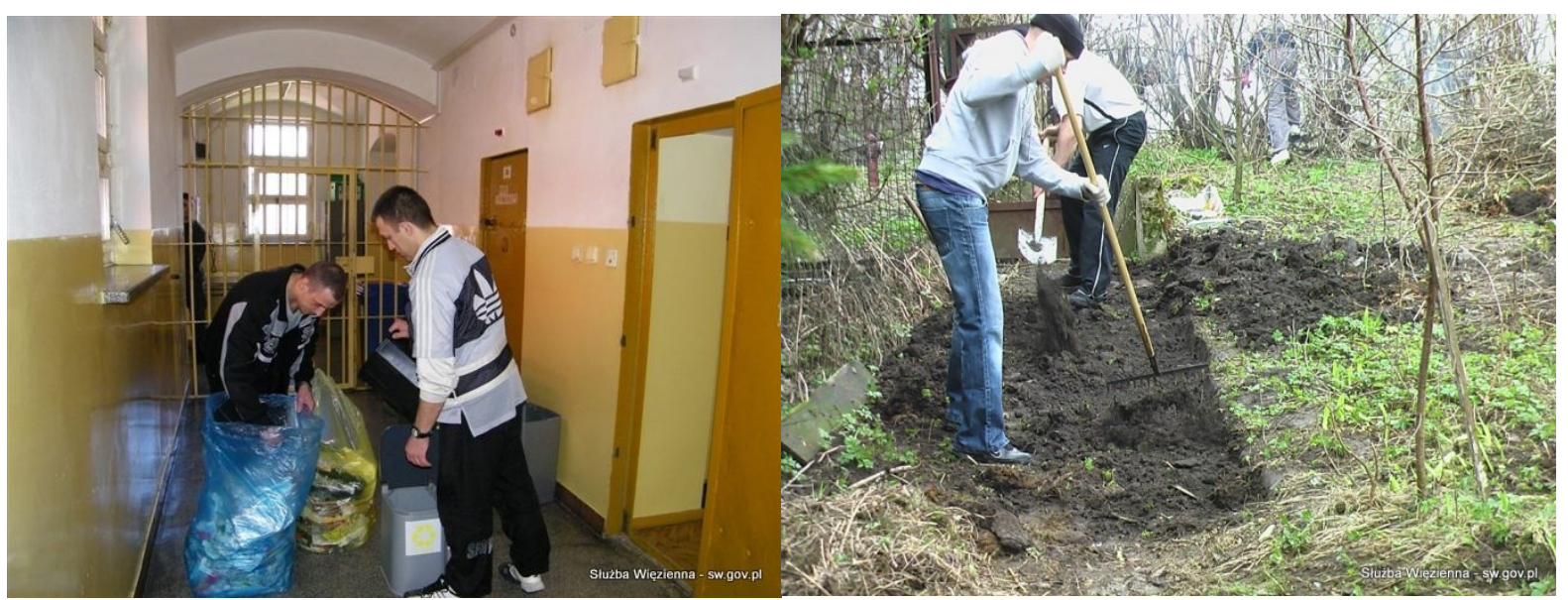

Foto. 2. Współpraca w zakresie bezpieczeństwa ekologicznego we wspólpracy SW i jednostek samorządu terytorialnego w ramach akcji Dzień Ziemi, /17.04.2013/.

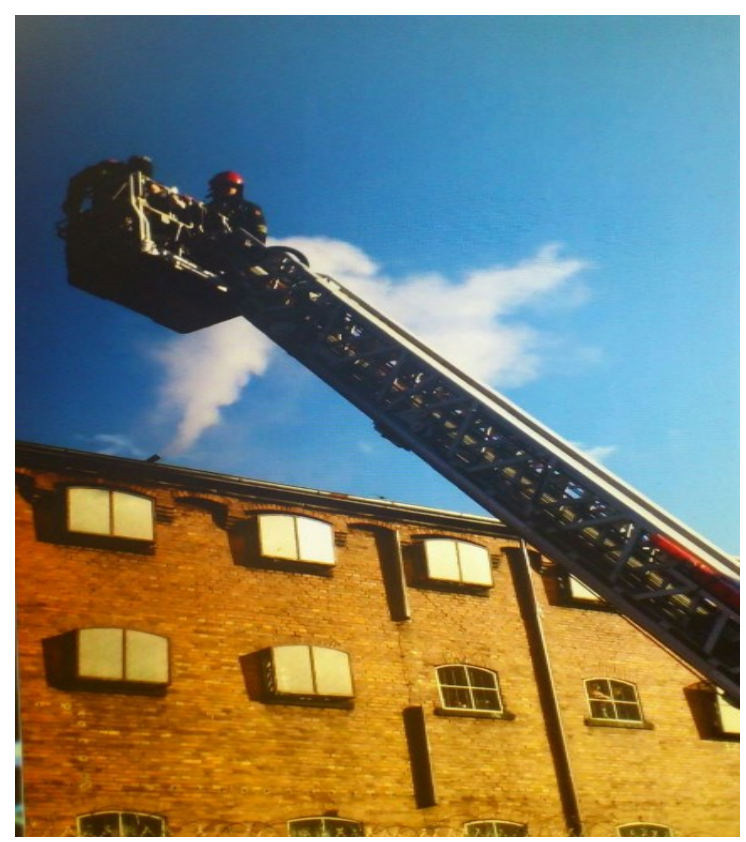

Foto 3. Pożar, ewakuacja wzięcie zakładnika - ćwiczenia ochronne, we współdziałaniu SW Policji, Straży Pożarnej, Mysłowice/ 18.04.2013/. 
Międzynarodowe Targi Techniki i Wyposażenia Służb Policyjnych oraz Formacji Bezpieczeństwa Państwa, z udziałem przedstawicieli wszystkich służb mundurowych i odpowiedzialnych za bezpieczeństwo państwa, Warszawa /17-19.04.2013/

- Specjalistyczne Ćwiczenia o charakterze ochronno-obronnym, we współpracy SW z Policją, Strażą Miejską i Sanepidem i lokalnym wydziałem bezpieczeństwa i zarządzania kryzysowego, Grudziądz /19.04.2013/

- Specjalistyczne Ćwiczenia o charakterze ochronno-obronnym, we współpracy SW z Policją, Strażą Miejską i lokalną jednostką wojskową, Morąg /19.04.2013/

- Zawody sprawnościowe służb mundurowych we wspólprsacy SW, Policji i Straży Pożarnej, Łowicz /22.04.2013/

- konferencja „Monitoring wizyjny w miejscach pozbawienia wolności” z udziałem przedstawcieli SW i Policji, Warszawa /23.04.2013/

- doskonalenie współdziałania w zakresie optymalnego wykonywania kary pozbawienia wolności, we współpracy SW, Policji, Straży Granicznej, prokuratury i sądów, Katowice/ 22.04.2013/.

Tabela 1. Dynamika wybranych typów wypadków nadzwyczajnych w polskich jednostkach penitencjarnych w latach 2001-2012.

\begin{tabular}{|c|c|c|c|c|}
\hline $\begin{array}{c}\text { Rodzaj wypadu } \\
\text { nadzwyczajnego }\end{array}$ & $\begin{array}{c}\text { Usiłowanie } \\
\text { samobójstwa } \\
\text { osadzonego }\end{array}$ & $\begin{array}{c}\text { Zgon } \\
\text { osadzonego }\end{array}$ & $\begin{array}{c}\text { Ucieczka z } \\
\text { terenu jednostki } \\
\text { penit. }\end{array}$ & $\begin{array}{c}\text { Napaść na } \\
\text { funkcjonariusza }\end{array}$ \\
\hline 2001 & 190 & 142 & 9 & 73 \\
\hline 2002 & 172 & 96 & 9 & 55 \\
\hline 2003 & 130 & 127 & 15 & 56 \\
\hline 2004 & 187 & 107 & 11 & 66 \\
\hline 2005 & 188 & 122 & 10 & 69 \\
\hline 2006 & 174 & 145 & 7 & 101 \\
\hline 2007 & 191 & 135 & 9 & 105 \\
\hline 2008 & 147 & 125 & 11 & 103 \\
\hline 2009 & 191 & 135 & 6 & 88 \\
\hline 2010 & 150 & 107 & 8 & 99 \\
\hline 2011 & 127 & 9 & \\
\hline 2012 & 145 & & & 62 \\
\hline
\end{tabular}

Źródło: opr. własne na podstawie danych statystycznych CZSW. 
Tabela 2. Dynamika wybranych typów wypadków nadzwyczajnych w polskich jednostkach penitencjarnych w latach 2001-2012.

\begin{tabular}{|c|c|c|}
\hline $\begin{array}{c}\text { Rodzaj wypadku } \\
\text { nadzwyczajnego }\end{array}$ & $\begin{array}{c}\text { Ujawnienie przedmiotów } \\
\text { zagrażających porządkowi i } \\
\text { bezpieczeństwu jednostki } \\
\text { penitencjarnej }\end{array}$ & $\begin{array}{c}\text { Klęski żywiołowe i } \\
\text { pożary }\end{array}$ \\
\hline 2001 & 631 & 20 \\
\hline 2002 & 748 & 17 \\
\hline 2003 & 832 & 23 \\
\hline 2004 & 977 & 27 \\
\hline 2005 & 1083 & 23 \\
\hline 2006 & 1205 & 21 \\
\hline 2007 & 1247 & 33 \\
\hline 2008 & 1274 & 18 \\
\hline 2009 & 1007 & 10 \\
\hline 2010 & 800 & 5 \\
\hline 2011 & 749 & 24 \\
\hline 2012 & 705 & 23 \\
\hline
\end{tabular}

Źródło: opr. własne na podstawie danych statystycznych CZSW.

\section{WNIOSKI}

Funkcjonowanie instytucji totalnych, jakimi są wszystkie jednostki penitencjarne, z założenia rodzi wiele opresyjnych sytuacji które skutkują generowaniem tzw.wypadków nadzwyczajnych z punktu widzenia bezpieczeństwa tych jednostek. Zmiany systemowe po 1989r. doprowadziły do zaniku zbiorowych wystąpień osadzonych o charakterze buntu, natomiast pojawienie się $\mathrm{w}$ jednostkach penitencjarnych osób z tzw. grup przestępczości zorganizowanej i osadzonych z krajów wschodniej Europy spowodowało zmianę dynamiki i akcentów związanych z zagrożeniem bezpieczeństwa jednostek penitencjarnych. Wzrosło zagrożenie bezpieczeństwa funkcjonariuszy więziennictwa i ich rodzin $w$ związku $\mathrm{z}$ nieformalnymi naciskami jakie w wielu przypadkach próbują dokonywać na nich osoby bliskie osadzonym /rodziny, wspólnicy/. Wiąże się to z czynami o charakterze korupcyjnym, bądź z dostarczaniem w sposób nielegalny na teren jednostek penitencjarnych zakazanych przedmiotów /narkotyki, telefony komórkowe/. Każdorazowo takie przypadki są zgłaszane jednostkom policji. Podejmowanie działań profilaktycznych przez Służbę Więzienną w ym zakresie powoduje generowanie nowych form oddziaływania na jednostki petnitencjarne ze strony osadzonych i ich bliskich. Współdziałanie służb dyspozycyjnych $\mathrm{w}$ zapobieganiu 
zagrożeniom dla bezpieczeństwa jednostek i osób w nich przebywających jest jedyną skuteczną formą zapobiegania rozwojowi tych negatywnych zjawisk.

\section{References}

[1] Borowski A., International Letters of Social and Humanistic Sciences 1 (2013) 14-18.

[2] Borowski A., International Letters of Social and Humanistic Sciences 3 (2013) 69-74

[3] Borowski A., International Letters of Social and Humanistic Sciences 5 (2013) 79-83.

[4] Borowski A., Podoficerowie w Stużbie Więziennej, w: (red J. Maciejewski) Grupy dyspozycyjne społeczeństwa polskiego, Wrocław (2006).

[5] Borowski A., Stużba Więzienna jako grupa dyspozycyjna, w: (red. J. Maciejewski, O. Nowaczyk) Bezpieczeństwo narodowe a grupy dyspozycyjne, Wrocław (2005).

[6] Borowski A., Rola instytucji totalnych w zapewnieniu bezpieczeństwa jednostki $i$ społeczeństwa, w: (red. D. Kowalski, M. Kwiatkowski, A. Zduniak) Edukacja dla bezpieczeństwa, t. 2, Lublin 2004.

[7] Borowski A., Czynniki dezintegracji społecznej funkcjonariuszy więziennictwa i ich rodzin; (red. J. Maciejewski, W. Nowosielski) Tożsamość społeczna grup dyspozycyjnych Wrocław (2009) .

[8] Maciejewski J., Socjologiczne aspekty bezpieczeństwa narodowego, w: (red. J. Maciejwski) Socjologia tom XXXI Wrocław (2001).

[9] Zagórski Z., Socjologia bezpieczeństwa. O potrzebie nowej subdyscypliny, w: (red. J. Maciejwski) Socjologia tom XXXI Wrocław (2001). 